\title{
Editorial: progress in Green Economics: ontology, concepts and philosophy. Civilisation and the lost factor of reality in social and environmental justice
}

\author{
Miriam Kennet \\ The Green Economics Institute \\ 6 Strachey Close, Tidmarsh \\ Reading, RG8 8EP, UK \\ E-mail: greeneconomicsinstitute@yahoo.com
}

\begin{abstract}
The inaugural publication of the International Journal of Green Economics constructed formal foundations for the establishment of a new school of thought and an attempt to explore and capture current developments and thinking in Green Economics.

The current issue introduces the next step in the development of green economics with a philosophical exploration of our focus, along with investigating potential building blocks from other disciplines. The current issue of The International Journal of Green Economics solicits experts in their respective fields and invites them to share inter-disciplinary contributions to the nascent philosophy, ontology and methodology of Green Economics.

This editorial will also ponder some of the emerging and exciting questions in the field; introduce the contributors to this issue; and concludes by introducing the themes of future issues.
\end{abstract}

Keywords: Green Economics; environmental economics; ecological economics; methodology in economics; Green issues; ontology; reality; civilisation.

Reference to this paper should be made as follows: Kennet, M. (2007) 'Editorial: progress in Green Economics: ontology, concepts and philosophy. Civilisation and the lost factor of reality in social and environmental justice', Int. J. Green Economics, Vol. 1, Nos. 3/4, pp.225-249.

Biographical notes: Miriam Kennet, Founder and Editor of the International Journal of Green Economics, bases the journal's concept on the opportunity to provide intellectual rigour and support for the development of green economics at the highest levels. She looks for inter and trans-disciplinary knowledge from academia, government, politics, NGOs and business. Kennet is trained equally in economics and environmental science having experience of learning and research from Leeds, South Bank and Oxford Universities. She is currently investigating the social, environmental and economics effects of the supply chain while at Keele University. Her research interests are corporate environmental strategies, economic theories, environmental science, distributive justice, supply chains and stakeholder theory. 


\section{Background and rationale for this next step in Green Economics}

The urgency of our Green Economics Project, which is the implementation of social and environmental justice, has accelerated since the inception of the journal. Social and environmental injustice significantly affect the world economy. Dr. Rajendra Pachauri, the chair of the Intergovernmental Panel on Climate Change, warns that "the very survival of the human species is at risk" (Lean, 2005). Public perception of our position in the world is altering, and the fragility of our survival and well-being, our economy and security is becoming much more evident (Pachauri, 2007; Stern, 2006; Raudsepp-Hearne et al., 2005). Pachauri in McCarthy (2007) worries that "we are doing things that have not happened in the last 650,000 years".

The polar ice caps are contracting at $7 \%$ per decade and may completely disappear, creating an ice-free arctic by the end of this century. Sea levels are expected to rise by at least $3.1 \mathrm{~cm}$ per decade or between 40 and $59 \mathrm{~cm}$ over the century (Pearce, 2007, pp.8-9; Pachauri, 2007) and this could permanently displace up to 200 million people (Stern, 2006). In the case of the Bangladesh delta environment, a full $2 \mathrm{~m}$ global rise in sea level coupled with a $1 \mathrm{~m}$ rise in local subsidence, would lead to a loss of $26 \%$ of habitable land (Viles and Spencer, 1995). It is also reported that the Gulf Stream had reduced by $30 \%$ between 1957 and 2004 (Pachauri, 2007). With predicted global warming of between $+2 \%$ to $+4.5 \%$ or up to $+6 \mathrm{C}$ by 2100 (Lynas, 2007), - the warmest period on earth since the time of the dinosaurs - coral reefs could become almost extinct; Amazonian rainforests will turn to desert; with up to $40 \%$ of species becoming extinct (Stern, 2006); drought would severely reduce most African and Mediterranean agricultural yields with desert encroachment in Italy, Spain and Greece (Stern, 2006, pp.18-19), making polar regions attractive to farm.

The Millennium Ecosystem Services Assessment (Raudsepp-Hearne et al., 2005) found that " $60 \%$ of a group of 24 ecosystem services examined by the MA are being degraded: this is the first comprehensive audit of the status of Earth's natural capital". There has been a rise in non-linear events, including: "disease emergence, abrupt alterations in water quality, the creation of 'dead zones' in coastal waters, the collapse of fisheries, and shifts in regional climate", as well as the specific threat to drylands. "These ecosystems are particularly fragile, but they are also the places where human population is growing most rapidly, biological productivity is least, and poverty is highest". Nutrient loading was also found to be an important driver of ecosystem damage such as climate change and habitat loss.

All of these changes are believed to be developing, which makes our task urgent and compelling. If nothing is done, the Stern (2006) Report, predicts a fall of between $3 \%-5 \%$ in global output each year, with a combined decrease in global consumption of $20 \%$.

Further, our current economic system perpetuates poverty, inequality and social injustice. This is supported by a UNICEF Report (2007) about the well being of young people in the UK, a country which has the fifth largest economy in the world, but it has the overall worst standards among the 25 richest nations, in terms of the well being and happiness of its young people. 
"The UK ranks in the bottom third of the country rankings for five of the six dimensions reviewed. Although, higher in the educational well-being dimension, the UK lags behind in terms of relative poverty and deprivation, quality of children's relationships with their parents and peers, child health and safety, behaviour and risk-taking and subjective well-being."

The report raises significant questions about how the pursuit of economic wealth, as current attained and measured, may actually detract from contentment, when it reduces time spent with family and friends or meeting people's fundamental needs.

Seventy percent of the world's 1.2 billion people in life threatening poverty, according to a UN Report (Firth, 2006) are women and children. Only 1\% of the world's titled land belongs to women (Firth, 2006). Gendered domestic violence is the single largest global cause of female morbidity, more than war, traffic accidents, and cancer! (Smith, 2006). It is therefore vital to redress the balance of poverty and power between men and women on the planet. Significantly, Wangari Maathai winner of the Nobel Peace Prize for planting trees was herself subject to domestic violence (Newman, 2007). She regards her most important achievement as becoming the first woman in Kenya to attain a doctorate in science and is proud to be a passionate human rights activist. Even in her extreme success, as a Nobel Prize Winner, she still struggles to be recognised as a serious scientist. In fact she explains the things that matter in society. She likens this to an African stool.

"The three legs represent three critical pillars of a just and stable society. The first leg stands for democratic space, where rights are respected, whether they are human rights, women's rights, children's rights, or environmental rights. The second represents sustainable and equitable management of resources. The third represents cultures of peace. The seat represents society and its prospects for development."

Maathai (2007, p.295) says that she aimed to protect the world's second lung, The Congo Basin Forest. These three pillars have got lost in the drive for global economic success, ever increasing profit, industrial productivity and trade flows as defined by mainstream economics. This drive has, up to now, justified the complete destruction of much of our habitat, and this is what Green Economics seeks to addresses and start to reverse.

\section{The meaning of Green Economics}

Primarily the aim and meaning of green economics is to create economic conditions where social and environmental justice thrives and benefits all people everywhere, as well as non-human species, nature, the planet and its systems. New analyses from the Green Economics Project are starting to conceptualise alternative methods and solutions to deal with current gross injustices and resulting damage to societies and to ecology.

\subsection{Green Economics has a wide and inclusive scope}

I am often asked what green economics means, and I believe it signifies the means for implementation of social and environmental justice, both as a 'means' for change and its attainment as an 'end' in itself. The dilemma is how to reconcile what can and often do appear to be contradictory choices favouring the environment over justice or vice versa. We cannot have one option instead of another one, as they are ultimately interdependent. 
We must join up our thinking and consider all the factors. This is the exact opposite of current thinking in mainstream economics practice where awkward elements are factored out and dismissed as 'externalities'.

As already mentioned, to reduce inequality and injustice and to promote equity are important ways to provide social and environmental justice at the same time. To be an environmentalist or a green without considering social justice as well, will not achieve this. For example, the education of women reduces the birth rate, which in turn reduces population, which in turn reduces pressure on ecological resources.

In less developed countries, the exploitation of people in poorly paid farm labour and in sweatshops, exploiting crops and resources such as water, to supply goods to the global supply chain, entails environmental degradation and even desertification. The over-use of water to grow salads for developed countries' supermarkets, for example, reduces equity of access to local resources for local people. The global extension of multiple retailers' supply chains through off-shoring, near-shoring and host country subcontracting increases product miles travelled, thus increasing the carbon footprint. In the long run, the whole of humanity and the planet loose out.

\subsection{Green Economics explores evolving realities}

The green economics philosophy approach requires that our economics models reflect real complexity. Current world trade systems require us develop better tools for analysis. Simplistic common economic assessment tools such as comparative advantage or cost benefit analysis do not provide a complete picture of today's increasingly complex intra-industry and intra-firm trade, which is currently estimated at $40 \%$ of all goods exchanged, (Ietto-Gilies, 2006). The 'truth' or the wise choice or 'answer' insofar as it exists, is often hidden, unclear, multi layered and multi faceted. We have begun to model this with such tools as Geographical Information Systems and climate modelling, and so we can no longer afford a simplistic economics path, which 'factors out the facts'. We cannot possibly hope to understand or explain all the complexities of reality, but economics must accept that they exist and we must begin to factor many of them in.

\subsection{Community and responsibility: positions in Green Economics}

One of the distinguishing aspects of the green position according to Salleh $(1997, \mathrm{p} .4)$ is that "Greens assume that since environmental damage impacts on people universally, it is to everyone's advantage to solve it. No particular grouping is seen to be better placed than any other to save the earth from human excess". This is in contrast to the socialist position, which argues that damage is caused by capitalists and capitalism and also to Porritt (1984, p.116) who proposed that middle class entrepreneurs would ultimately become the agents of change, and to Dobson (2000) who suggested that conditions, not simply people themselves, must change.

The dilemma is not 'do we save the planet by coercion?' so that people and planet have a better bundle of resources and are enhanced, but rather "do we go much further with our decision making and investigate the consequences of our actions and choices?" Just as there is no place called 'away' as in 'throw it away', there is similarly no activity without consequences and we need to understand and to factor consequences into our concepts of reality and into our explanations. 
Jacobs (1991, p.x) distinguished between people who are greens and people who are environmentalists. He suggests that 'green' denotes:

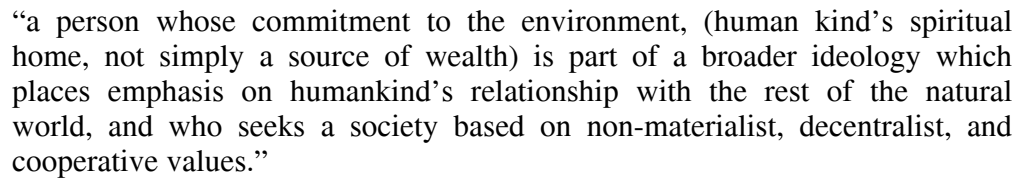

Dryzek (1997) provides a fascinating analysis of the spectrum of green positions, from those who believe the market will adjust price mechanisms to provide the solutions, those who believe in administrative and regulatory solutions, those who believe in eco modernisation (Barry, 2007), those who believe in the human capability for problem solving and lifestyle greens; and green activists. Dryzek (1997) identifies Green Radicals, who are divided into Green Romantics and Green Rationalists. Green Romantics reject much of the enlightenment and see salvation within individual consciousness raising, and include deep ecologists, bio-regionalists and some anti-globalisation activists. These are contrasted with Green Rationalists, including animal rights activists, who largely embrace much of the enlightenment agenda of equity, reason, rights, science and progress but they all reject industrialism, as currently constructed although changes within industrialism are advocated by Hawken et al. (2005) and by Korhonen and Strachan (2004) through industrial ecology. Other environmentalists argue for a market based solution (Anderson and Leal, 2005) or solutions based on incentives, such as price or technology or sustainable development (Redclift, 1987; Schmeidheiny, 1992). They seek transformation and a compatibility between business as usual and ecological improvements. Ecological modernisers also seek compatibility between economic growth and the imperative to protect environmental quality, perhaps through environmentally friendly products for example (Barry, 2005, p.304). Pigou (1920) suggested that market failures actually caused environmental degradation and that the political processes could correct the problem. Countries such as Germany, Japan, the Netherlands, Norway and Sweden have pursued strategies towards environmental excellence in industrial products, (Dryzek, 1997, p.137). Green economics position along this spectrum seems likely to be in the radical Green Rationalists area but with strong influences from the Green Romantics.

\subsection{Existing definitions and descriptions of green economics}

Bateman (1997, p.37) describes the green economy as "an extension of the conventional economic approach to encompass, among others, distributional equity, and environmental quality objectives".

He suggests that this could involve:

- "the rejection of unlimited demands and wants by rational economic man (homo economicus), the archetypal selfish (greedy) inhabitant of the unfettered market economy and in favour of a more collective economy based on people's needs".

- "an economy that is capable of replicating itself on a sustainable basis"

- evolution over time to decouple the growth in economic output (activity) from the environmental impacts

- the use of technical changes to be more efficient

- freezing or reduction of the levels of rates of change in the economy and population. 
Anderson (2006) identifies several possible postures in relation to the boundaries drawn around conventional economics. These are: conventional economics operating within its boundary; environmental economics as venturing beyond the boundary but on the basis of the paradigm and assumptions provided by what is within the boundary; green economics that "is not only not constrained by the boundary but also profoundly suspicious about the boundary and what goes on there". Anderson (2006) also describes green economics as concerning itself with "the interaction between human economic activity and the natural world, and both directions of that interaction, human dependence on the natural world and the human impact on it. At the centre of Green Economics is the understanding that the economy is dependent on the natural world and could not exist without it" (pp.18-19).

\subsection{Balancing social and environmental equity in a practical way}

Kennet and Heinemann (2006a) suggest that the social equity in green economics goes further than distributional equity, (currently used by main stream economists) as it involves ensuring that a social transformation is achieved both during the process and also in the end, rather than confining economic analysis within subjective boundaries of distribution activity and this is a very important distinction. Similarly, environmental quality is a more limited concept and does not require consideration of the impacts on the groups with which we are concerned, such as people with no voice or legal standing, non-human species, and the planet. Environmental justice means ensuring all these groups and entities have what they need and that they benefit from economic activity.

\section{The objectives of Green Economics}

There are three main objectives of green economics.

1 First to create economic conditions where social and environmental justice thrives and benefits all people everywhere, non-human species, the planet and its systems.

2 The second means to achieve our aims is also ambitious: to reform mainstream economics into a discipline which no longer supports or accepts that only a small minority can be wealthy, but rather one which works towards a fair and equitable society which lives within its means in all senses. Further green economics seeks to re-examine new and broader versions of reality, beyond simply the views of the rich and powerful, to hear different voices, as proposed for example by feminist theory (Ghilligan, 1982). This will no longer use ceteris paribus as a limitation of scope, or see rational economic man 'homo economicus' as a benchmark, but rather hears the voices of everyone and everything.

It is no longer enough to say, as one extremely well-known publisher (OUP) said to me recently "we don't do social or the environment, we just do economics and econometrics". As Anderson (2006) says "The world needs a new economics more than it needs a new anything else". Green economics is trying to provide that broad 'out of the box' thinking and to combine trans- and inter-disciplinary studies to counteract this narrow thinking, whereas one of the big drawbacks of mainstream economics thinking is its lack of influences and learning from other areas. Anderson 
also requires that a debate about values becomes an integral part of green economics, in addition to concern with 'inputs' to the economy; with 'externalities' and with the imposing of costs without a bargain taking place, which start to ensure the recompense.

As Welford (2007) exhorts, "if we were to emphasize moderation and sufficiency rather than maximisation of output, consumption, incomes and profits, this would have a radical and fundamental impact on the way we lead our lives and the way we treat the environment".

3 The third objective of green economics is to go beyond reforming main stream economics and to establish the new discipline or school of thought of green economics in order to provide the means for all people everywhere to participate in the economy with equal power, equal rights and with equal access to decision making. The accumulation of riches, and power by the few, who seize those of the many, often by legitimate means, as a result of our current economic system, needs to end. Significant and powerful claims are made, that the first issue of this journal contributed towards the establishment of a new discipline in economics (Reardon, 2007) or a school of thought (Anderson, 2006) and towards developing ontology in mainstream economics (Lawson, 2007).

\section{Progress in green economics; a new relationship and respect for nature's role in economics. Factoring nature back into economic theory}

It seems clear that a new era is beginning. There is a huge global spiritual revival, on the one hand, with the rejection of global secularism. On the other hand, there is an increased seeking for refuge in the comfort of scientific knowledge and progress. There is also a desire to find a sense of global community and belonging in a time of change. This, in some respects reminds us that our early spiritual and shamanistic aspects of our early beginnings, charted by archaeologist Mithen (2003), were characterised by spiritual searching for comprehension of the natural world.

Humanity's perspective of the wild untameable character of nature is becoming clearer. Just when men and women thought they had completely tamed nature, climate change has forced a philosophical re-think of our position in the universe and our role as stewards of nature on earth. We are beginning to realise that rather than using science to control nature, we are actually going to have to use our knowledge to live within it and to respect it, as it is much more powerful than we will ever be. Early religions and spiritual life factored this in, and I think that green positions and economics theories can learn from this understanding, and factor the power of nature and the earth back into economics. This early acceptance of the power of nature allowed for acceptance of the power of women too. Our own evolution, from tiny placental mammals, in the Mid Jurassic, began at the time when dinosaurs appeared to hold the key to the future. Instead, it turned out to be these new creatures, the mammals who came to dominate the earth (Hecht, 2007). We should not underestimate the importance of retracing our steps and pulling back from developments or evolution that do not work or are not sustainable. 
Table 1 Vital new areas covered by the green economics debate

Major topics

- The limits and feasibility of civilisation, city dwelling and agriculture under Global Environmental Change (GEC)

- An economic and ecological audit of 10000 years of civilisation

- Human habitat, ecosystem crises, biodiversity and current species extinction

- The economics of human-created (anthropogenic) GEC

- The economics effects of climate change and instability

- The effects of GEC on transport and energy

- The effects of transport and energy use on GEC

- Loss of $40 \%$ of species, biodiversity and current mass extinction

- The future of agriculture and food provisioning

- The future role of global corporations

Major potential solutions/ways forward

- Taking account of GEC into mainstream and green economics

- The ambiguous role and limits of stakeholder theory

- The economics of displacement and migration due to global environmental change

- Ways to address the risks and problems of mitigation

- Eco-efficiency and economies of scale

- Appropriate levels of local and global technologies and economies.

- Bioregionalism, re-interpretations of Schumacher

- Implementing low carbon living

- The role of spirituality in addressing problems of climate change in industrial and agricultural societies

- The role of the community and the common good in economics.

- The ambiguous role of 'development' and 'growth' in social and environmental justice

- Managing the economy and society for lower growth and lower consumption

- Nuclear Fusion

- Harnessing new sources of power

- Greening the supply chain and its structures

- Exploring the impacts of the supply chain

Revision of traditional assumptions in economics

- Cooperation or competition

- The role of corporations, stakeholder theory and limited liability

- Revision of perception of the role, economic impact and benefits of aviation

- Interim environmental solutions and how they may delay and divert moves towards social and environmental justice

- Timescales and long term responsibility

- The importance of social and environmental justice

- The importance of feminist theory methodology in green economics 
In order to address these topics and revisions, new critical ways of thinking are needed. They include questioning the scope and meanings of 'economics' and of 'facts', 'evidence' and 'reality' in positivist economics, as well as what are 'rational and reasonable choices'. Other economic and ecological paradigms from feminism, spirituality and Eastern religions question weaknesses in mainstream economics and how it exploits and oppresses certain groups and over-rewards others. Other disciplines in the natural and social sciences and the humanities can increase our understanding of 'economics' and of social and environmental justice and how can it be achieved. We need to adopt new timescales and long-term responsibility for justice and future survival.

\subsection{Re-conceptualising uselexchange values, the good life, distributive justice}

This section considers eight areas which urgently need to be reviewed.

\subsubsection{The limits of civilisation - 10000 years of town dwelling - an audit}

We need to assess the viability of agriculture and of urbanisation in a planet during rapid global environmental change and to establish the best course of action on climate change. The issues of population growth, people displacement and scarce resources are important economic questions. Several different groups of writers have started to address these problems, including those from Global Environmental Change and Geography (Goudie, 1997; Simmon, 2007; Viles and Spencer, 1995), and from a Green historical, prehistoric or indigenous economic perspective (Diamond, 2005; Ponting, 1991; Sallins, 1974).

Further it is vitally important to research into what can be done after the time when agriculture is no longer viable due to climate change.

Barry (2007, p.235) highlights the green political economy and Limits to Growth argument that exponential economic growth is impossible and also 'undesirable', both because it produces inequalities, and also because "beyond a threshold, it does not add to and may even take away from life satisfaction and quality of life".

Even the project of 'civilisation' may also be under threat. Civilisation literally means civis, the latin word for townsman or citizen, civis, adjectival, civilis, which implies some form of urbanisation. To be 'civilised' essentially meant being a townsman, governed by the constitution and legal statutes of that community. However, mega-cities surpass human-scale communities, their own local ecosystem services and the carrying capacity of their own hinterland. Many are also coastal and so are in danger of sinking beneath a rising sea level. There is an urgent task, fundamental to green economics, to reanalyse 'civilisation' and to calculate how human living and economic patterns can adapt for survival. This is the work of green economics.

Agriculture enabled cities to develop, but agriculture is now under threat from a greatly increased global temperature and from climate instability and from effects such as floods, droughts and growing desertification. Economics can no longer be confined to analysing 'standard of living', without considering civilisation's ultimate dependency on natural resources. We need to investigate whether 'sustainable cities' are the answer or if we should explore some other kind of social or economic organisation. 


\subsubsection{The human habitat and ecosystem services crisis and the current mass extinction}

This is affecting the ability of our habitat to sustain us all, as a species. Since Green Economics means provisioning of our needs, it is becoming clear that our economics is running into limits of expansion and we need therefore to re-think the whole premise of our mainstream economics thrust. The current rising economic powerhouse is China and but its natural eco-systems, are already cracking under the pressure.

\subsubsection{The economic costs of anthropogenic global environmental change}

This was highlighted by the Stern (2006) Report and needs to be analysed much more fully across a number of scenarios. It is not certain if we will have catastrophic short term extreme climate change, which will lead to people displacement, entailing very rapid habitat and agricultural destruction, due to an acceleration of feedback mechanisms as suggested in Hecht (2007), or whether economic action will be taken on a global scale to halt these changes, or whether the climate changes may slow down. Therefore economic planning must take place:

- to limit further human induced global environmental change

- to mitigate this effect economically

- to plan for a new economic environment where global environmental change may have a far reaching effects and where there continues to be uncertainty in the future

- to cope economically, and to design an economics for such scenarios, for example where large cities become flooded or unusable

- $\quad$ to plan for an economy during a period of structural economic uncertainty and major climatic and other shifts, including a lack of availability and viability of natural resources or lack of viability of agriculture upon which we are reliant.

\subsubsection{The economic impacts of a major displacement of people will result from global environmental change}

The economic impacts of major people's displacement will result from global environmental change and economic research needs to be applied to consider the people affected and the new host communities and potential resultant conflicts over resources (Diamond, 2005).

\subsubsection{The limits of mitigation}

Tony Blair, the UK Prime Minister recently suggested that persuading people to change their lifestyle would be futile, and that science and technology could prevent climate change, and allow us to carry on with current aviation levels. This caused a negative reaction which indicated that actually, a change in lifestyle is what people are looking for rather than mitigation of the worst effects.

There is a slow public realisation underway that deep global environmental change and climate instability needs to be prevented and slowed down at all costs. Building sea walls round small communities will never be adequate to protect all human settlement threatened in future for example by sea level rise. Significant non-linear changes will occur that are directly influenced by our emissions of greenhouse gasses including 
Methane and $\mathrm{CO}_{2}$, and we have to choose how devastating their impact and magnitude is planned to be. Natural mechanisms could take 30 years or more to reveal the consequences. The realisation has come that environmental actions now, are much more beneficial than actions later, which is directly contrary to the prevailing economics practice of discounting of the future, which values and protects the present use of resources over the future.

\subsubsection{The real effects of eco-efficiency and economies of scale, and new patterns of world trade need to be urgently investigated}

This has been started by Iettto-Gilies (2006), Kennet (2006), Grimwade (1989), Dicken (1986) and Bridger (2006).

\subsubsection{Localisation versus appropriate technological and economic units}

One of the key fault lines of debate is that of the extent and meaning of localisation or appropriate levels of technology. Generally this involves purchasing local produce; thinking globally and acting locally and it is promoted benignly by such organisations as the Soil Association. Localisation and self-reliance are important features of green political economy and would include smaller and more local markets, but Barry (2007, p.232) emphasises that this does not support arguments for a 'closed economy' or no trade whatsoever. This fault line is very much more significant than first appears. A less benign aspect is in its incarnation of the theory of Blood and Soil (Bramwell, 1989), where it has also has been abused by the extreme right to promote xenophobia and is the complete opposite of the concept of free trade and free movement of peoples, goods and services. Lately both strands promote localisation of food, and the hope of local governance and visibility of the provenance of our food, as well as the reduction of food miles. This is an important development and we must take care to ensure that benign uses of these arguments prevail.

Quite distinctly from the above debate, the German Greens, i.e., Green Politicians and others are very keen to promote Gerechte Globalisierung - or a much more just globalisation. This perspective tends to focus much more on democratic access to decision making and for an alternative definition of globalisation which is different to the anti-globalisation position and to the localisation debate.

\subsubsection{Envisioning a lower growth economy}

This requires research into how we would pay for social and public services, whilst discouraging wasteful economic activity and economic growth in the conventional sense. When a steady state economy was first proposed by Mill (1859) and then by Daly (1974) it was regarded as a pipedream, however there is now a powerful movement for a reduction in GDP growth, even in China.

\subsection{Revision of economics techniques and traditional assessments \\ 4.2.1 Cooperation or competition?}

Are humans always profit maximising? Primate studies indicate that cooperation is an important aspect of society, De Waal (2005), which surprises mainstream economic theorists. Even concepts like the prisoners dilemma and the tragedy of the commons need 
to be partially revised as cooperation is regarded as a valid option for human behaviour. However, De Waal (2005, p.42) has shown that rather than Hobbes' idea that mankind is trapped in a relentless pursuit of power, coalitions are a better key to understanding human nature. He explains that if we were asked to kill people to avoid a flu epidemic spreading we would refuse, as "we refuse to strive for the greatest happiness of the greatest number (the school of moral philosophy known as utilitarianism,) if doing so violates the basic inhibitions of our species".

De Waal (2005, p.189) cites the Analects of Confucius. Confucius (551 BC to 661BC) asked if there was a single word that summed up all of one's life and he said it was reciprocity, "don't do to others what you would not want yourself"; De Waal believes that reciprocity arose from sharing of meat and a kill and is strongest in capuchin monkeys, chimpanzees and people. This, he suggests involves keeping a balance of good deeds which we expect to be roughly equal and reciprocal.

In Nichomachean Ethics (Meilke, 1994) Aristotle argues that a concept of reciprocity (antipepinthos) may not be adequate to account for corrective and distributive justice. He argues that we need to introduce the idea of an exchange bond and exchange justice which provides and governs the reciprocity (Meilke, 1994, p.10). This is on the basis of proportion (kreitton) of things, and not on the basis of equality (of things, not of people), such as exchanging a house for a shoe. In re-conceptualising what we mean by 'value', there will have to be further consideration required as to how each individual decision based on value would be assessed, in the light of absolute boundaries to consumption that might be imposed by ecological restrictions to human activity.

Aristotle also described 'use value' meaning the natural properties of an item, in order to meet particular needs, this was distinguished from 'exchange value' which involved a given sum of money representing amounts of what is made, and this is the price. This differentiation hints at the attempt to determine an objective value of goods that might be different to the price the goods are exchanged for, which is an important starting point for a modern critical assessment of human consumption. He also identified want satisfaction 'chrei' as demand or need. Aristotle proposed that inequality, meaning insufficiency, incommensurability not 'summetra', of demand leads to exchange. This is distinct from 'Nomisma' meaning money, which is a cultural invention. Clearly there is much scope for re-examination of all these concepts and to reposition them in the light of our current knowledge of our needs as a species and the environment.

\subsubsection{The role of corporations, stakeholder theory and limited liability}

The role of the corporation and stakeholder theory is also fiercely contested. Is the corporation part of the solution or the cause of the problem or both (Dicken, 1986; Freeman, 1984; Sachs, 2005; Hawken et al., 2005; Welford, 2007; Kennet, 2006a-b)? This subject is of significant relevance to Green Economics as it changes much of the conventional wisdom about perfect competition and the invisible hand of market forces at a time where those forces are replaced or manipulated by large corporations, and we invite further research on this subject.

\subsubsection{Assessing the impact of interim environmental solutions}

It is important to critique the implementation of eco taxes, and the relative importance of different solutions, such as contrasting carbon trading versus regulation. The economic discussion needs to be significantly advanced and made relevant rather than just 
explaining simplistic standard concepts. It is unclear, for example, whether short term techno fixes or market fixes actually delay more far reaching solutions to environmental problems including life style changes. This opens a wide scope of sophisticated and important assessments of the benefits and problems of direct and indirect solutions on offer.

\subsubsection{Timescales and long-term responsibility (Chong, 2006; Lynas, 2007)}

New periods, timescales and responsibility are required to be much more long term than business cycles. We need to act immediately to try to reverse or slow down undesired feedback effects. Researchers have begun to look back to the period before the dinosaurs for climate, temperature and carbon indicators and species extinction indicators. This is in order to capture the long-term trends and equilibrium conditions required that get lost in the typical short-term analysis of conventional economic analysis.

\subsection{Methodological areas of debate}

\subsubsection{Green political economy or economics?}

Auguste Comte, according to Rostow (1990), proposed that economic behaviour is embedded in the larger setting and more complex motivations of human beings in society and therefore that we require a more general social science, before adequate economic analysis can be conducted. This idea has been addressed by Mill, Marx, Marshall and Schumpeter, and Pigou who each attempted to relate the externalities of industrial production to a discussion of their wider, societal costs and benefits. Against this background, there has been debate about the whether the role of Green Economics ought to lie within 'political economy' rather than within 'economics' (Reardon, 2007).

Barry (2007, pp.231-240) believes that 'green political economy' is much more explicitly political and prescriptive in its analysis. It challenges neo classical economics view of 'the good life' as one based on an ever growing consumption achieved through economic growth. In particular green economics proposes 'quality of life' or 'well-being' rather than 'growth-mania' (Daly, 1974) with suggestions that since its scope is wider than 'economics' itself, Green Economics ought to belong in political economy. We would contest this, with the response that 'economics' now needs to be wider in scope in order to meet today's pressing needs for environmental and social justice, and that allowing economics to remain half a discipline, letting down one-fifth of humanity into poverty, and ruining the environment for everyone, is no longer a viable discipline, and needs urgent reform and a reality check.

Barry (2007) reveals that Green political economy builds on ecological economics but is more explicit in its political aims of arguing for an alternative mode of economic organisation, and he stresses its connection between analyses and political struggle and between theory and practice.

\subsubsection{The limits of positivism and new conceptions of reason (Lawson, 2007; D’Agostino, 2006; Lawson, 1997)}

Evidence is mounting that enlightenment theoretical certainties of western values of "reason, liberalism, measurement and positivism" fail to provide a complete explanation of recent global developments. This is very evident in economic logic and 
outcomes. However, ironically it is the very lack of inclusion of positive natural science data that is missing. This is why more and more people from all over the world are starting to notice a mismatch between economics as it is established and the economics we require to deal with today's reality.

D'Agostino (2006, p.16) goes further and provides an interesting distinction between "planned and organised economic activity such as Fordist/Taylorist style production in economics" on the one hand, and 'improvisation as economic reason' on the other. He suggests that the planning model of rationality suits rational choice theory, and cost-benefit analysis, "The telos of Fordist and Taylorist modernisation is precisely to simplify and stabilise ourselves and the world we work in". He reveals that the planning model suits a modernist project however, its limits mean that understanding the world and its volatility and inexhaustibility, can never be fully accomplished, because he reminds us "planning is feasible in situations that have been simplified and stabilised" (2006, p.17). Today's transactions and current open-ended contracts, preferred global supplier partnership relationships, and Service Level Agreements are more reactive, more situated, specific and imprecise and do not particularly suit this kind of planned working or economic prescription. Outsourced supply chains actually have no measurable boundaries and span global transactions, which are all interwoven and inter-linked with no possibility of control or complete visibility, at either end of the chain. Outsourcing is increasingly worked and controlled on a project basis, as normal organisational departments cannot respond to the dynamic and imprecise nature of activities. It is no accident that those of us working in these fields noticed a mismatch between economic theory, theories of the firm and economic reasoning and sought a new conceptualisation of economics reality and therefore instigated the Green Economics Project. Reality is a concept in economics we need to urgently re-visit. D'Agostino observes that an improvisational model of rationality is increasingly used in artificial intelligence, "that figuring out and acting are all mixed up together, and we need to act to figure things out". This development in the conceptualisation of reason, as a dynamic entity, could be supported by Salleh (1997) who relates it to eco-feminist analysis and claims that "eco-feminism is more than a manifesto, it lives in the actions of women", and it also could be supported by action research methodology for example advocated by Mies (1986, p.56). Similarly this could apply to climate change, where waiting to see what happens and then analysing it completely misses the opportunity to do something to rectify it. D'Agostino (2006, p.18) proposes this kind of reason "as improvisation might actually improve the quality of our engagement with the world and with each other".

\subsubsection{Establishing the role of feminist ecological theory in green economics}

Of 1.2 Billion people today in life threatening poverty, $70 \%$ are women and children (Ocampio, 2006). For every 400000000 men in poverty; 700000000 women are without access to adequate food, water, healthcare or sanitation and only $1 \%$ of the world's titled land belongs to women (Firth, 2006). This is a human tragedy for both men and women and the severe gender inequality needs to be addressed urgently. Domestic violence is according to Ocampio (2006) the single largest global cause of female morbidity, and a bigger killer than war, traffic accidents and cancer! In the UK alone, 
domestic violence is estimated to cost $£ 3.3$ billion annually, according to Smith (2006), meaning that inequality and violence against women are economic as well as social justice issues.

Common and Stagl (2006) wrote a book on Ecological Economics which did not mention feminism or women's perspectives on poverty. However King (2005) recommends that ecology does require a feminist perspective, and is incomplete with out it, and I regard it as an essential feature of Green Economics theorising and the distributive and social justice debate.

There has however, recently, been a sudden recognition of the power of nature, due to human induced climate change and this has emphasised its domination and stewardship over man and his habitat. This has reversed the 10000 year old trend and belief that man had of his own domination over nature, which is embodied in our patriarchal culture and religions. There is currently an enormous philosophical and psychological shift required in men's acceptance of their own vulnerability in relation to nature, which must also remind them of their own dependence on nature and thus on women. New cultural and economic organisations are needed to take account of this new reality.

King (2005, p.404) theorises that men have sought to dominate women for reasons which are not simply economic but rather they are uncomfortable with their reliance on women and nature. King shows the significance of the current merging of feminism and ecology as social movements which is contemporary with nature's revolt against human domination.

A fault line of contention among green thinkers and activists is the proper role of feminism and the idea of other voices (Ghilligan, 1982). King (2005) argues that "the ecology movement attempts to speak for nature as 'other' which has no voice". Feminism in our society represents the refusal of the original 'other' in patriarchal society to remain silent. Domination of sex, race class and nature are mutually reinforcing and are all resisted in the feminist movement. Marchant (1980) showed how the disenchantment with nature was necessary for scientific development and technological exploitation to take place. De Beauvoir (1949) called this transcendence over nature and described it as the work of culture and that of men, the process of overcoming immanence, as symbolised by women. By dominating nature, man attempts to forget how he is born of woman and needs women, and men are therefore afraid of the power of women over them.

It is thought that in ancient times this was harnessed in goddess power, which controlled and managed these feelings and kept them in balance. However, since the advent of agriculture and civilisation, there has been unchecked male power in both spiritual and economic life. This has led to an over-domination of male concerns over nature and women. This has in economics terms led to women owning only $1 \%$ of all titled land and the rest being owned and controlled by men. This must now urgently be reversed and brought into balance, according to the Ocampio (2006).

\subsubsection{The ending of oppression by people who literally own society and others who are owned by it}

This includes "the alienation of people in nature within their own social world, and the domination of the young by the old, of women by men, and of men by men". Bookchin (2005) suggests using collective wisdom, cultural achievements, technological 
achievements, scientific knowledge, and innate creativity for the benefit of the natural world, and he regards all ecological problems as having an origin in social problems (Dryzek and Schlosberg, 2005, p.398).

\section{An interdisciplinary and philosophical collection}

The journal will have a heavy concentration on philosophical aspects as nothing short of a complete re-conceptualisation of economics is required. There has been much interest in the philosophical aspects of our ideas which aim to reverse trends towards increasing numbers of people suffering terrible poverty, and also to end the serious degradation of the planet, and its resources. We need therefore to consult all types of philosophical discourses: past and present, on which to build a new world view. I think it especially important to open our eyes to notice what is going on around us. In the past history consisted of learning of the exploits and fortunes of kings and queens. However at each period there was an entire world of people, including women, the governed and ordinary people, whose experience was not recorded, and was not understood. We can argue that our concept of reality of those times can only therefore be partial, and incomplete. Today, we need to better understand our impacts and our rights. Not just those of the rich and currently powerful. The world belongs to us all equally, and to those who come after us, and to nature. We should not aim to run the planet on our own. If we wipe everything else out, we will not survive either. Humans are a young species, we are now reaching maturity, we have begun to understand the world around us and it is time to grow up and to behave with wisdom and foresight. We can no longer plead ignorance. The way forward is clear. The planet is our habitat and so we need to look after it and each other. Economics requires a much more differentiated and complex approach to reflect all these issues fully and correctly, hence a wider philosophical basis is encouraged by this journal.

\section{Introduction to the second collection of articles: progress in Green Economics}

\subsection{Section A - ontology and concepts}

\section{Tony Lawson, Cambridge University, An orientation for green economics?}

Lawson's (2007) involvement in the project to address environmental and social justice joins up the thinking in alternative circles - and begins to end the fragmentation in alternative economics, which makes green economics stronger as a whole. Lawson argues that an explicit systematic and sustained ontological analysis is required. By this he means the study of the nature of phenomena of a domain of reality. Lawson sees signs that such an orientation is being adopted in Green Economics and he defends the crucial ideas that underlie and explain Green Economics. 


\section{Professor Maria Mies, Cologne University, Patriarchy and accumulation on a world} scale revisited

We are also fortunate to have a contribution from Maria Mies, Patriarchy and Accumulation on a World Scale Revisited, who was the first professor of women's studies and brings a sound feminist as well as a developing country perspective, having lived in India for many years. Her thesis of patriarchy and accumulation was one of the founding building blocks to our thinking in Green Economics, although some of her ideas will be new to some readers. She is able to link development critique, international production, patriarchal critique and women's experience of world trade, with a rigorous economics and social theory analysis. She is also one of the few alternative writers to exhibit a proper understanding of the structure of modern international trade and to join up her thinking on feminism and patriarchy to these structural changes in trade. She reveals how the hidden work of women in the household, the work of subsistence producers working in the informal sector and the work of nature constitute the hidden underground of the capitalist world, economy and its accumulation model.

\section{Dr. Hazel Henderson, USA, 21st century strategies for sustainability}

Henderson provides a more spiritual and physical account of the economy. She discusses how current economic models drive today's unsustainable forms of globalisation, which is consuming $40 \%$ of all photosynthetic production, and is leading to the current mass extinction of other species. She proposes that technological innovation is needed to shift from fossil fuels to renewable energy, recycling and redesign industrial processes. She shows how fundamental research on the human brain now refutes most of economics core tenets.

\section{Professor David Simon, Urbanisation and global environmental change: new intergenerational challenges}

Simon provides a much needed physical reality check to the background of our lives, our economics and our social science discussions. We will all be affected by global environmental change and we all need to consider its physical manifestations and their implications. Professor Simon explains the main mechanisms of Global Environmental Change and builds on the findings of the Stern (2006) report into climate change and the 4th Assessment of Report of the Pachauri (2007). His paper outlines the bi-directional relationships between GEC and urbanisation and highlighting intergenerational equity issues that arise. He explains the 'green' in Green Economics, and reminds us how it is vitally important to remember there is much science within Green Economics. It is an economics which can deal with climate change as it is part natural science and part social science. His article serves to focus economists and social scientists minds on the physical impacts of the most recent of the last 10000 years of civilisation, including the construction of vulnerable mega-cities built on insecure natural resource foundations. 


\subsection{Section $B$ - philosophy}

Dr. Rupert Read, Norwich University of East Anglia, UK, Economics is philosophy, economics is not a science

Read is a Philosopher who investigates economics using philosophical analysis. With the abject failure of economics to meet the needs of people and planet - this kind of approach is what is needed, and whilst we may not agree with some of what he says, we think it is an important contribution to the debate. Read argues that Green Economics should eschew any claims to scientificity and scientific ambition, but rather we should embrace green economics as a point of view which has, at its heart, an endless love of life. He suggests that green economics is a philosophy rather than a science. We welcome other ideas which may be stimulated by reading the article.

\subsubsection{Buddhist philosophy papers}

We are delighted to have two notable writers in the related field of Buddhist economics. Schumacher's (1973) Small is Beautiful is widely believed to have given rise philosophically to parts of the green movement and its interest in Buddhist economics.

Hans-Gunter Wagner writing from China and Germany, Buddhist economics - ancient teachings revisited

Writing from China, Wagner suggests that much of Schumacher's original arguments were very pertinent but became subsumed by assumptions about what he meant. Wagner revisits the original works and discusses what Green Economics can learn from Buddhist economics. Wagner contrasts western economics with the content and assumptions of Buddhist economics in the canonical scriptures, and the Buddhist concept of happiness and economic action in general, as well as right livelihood. Distribution and sources of wealth are discussed. These are contrasted to green or ecological approaches to economics.

Professor Richard Welford, University of Hong Kong, Buddhist economics and corporate social responsibility

In complete contrast well-known sustainable development practitioner Welford, now based in Hong Kong, explores the corporate implications of Buddhism and the resultant possibilities for Corporate Social Responsibility. He has a large and devoted following among the business CSR community and among scholars interested in implementation. Welford remarks that most businesses have yet to come to grips with the transformations that are required to tackle the challenges associated with climate change, the overuse of natural resources, pollution impacts, and unsustainable levels of consumption. He argues that "a Buddhist approach supports the framework advocated by Springett (2006) in promoting the concept of sustainable development as capable of emancipating more democratic and inclusive approaches to living with nature and each other". 


\subsection{Section $C$ - methodology explored}

\subsubsection{Perspectives in green economics}

Volker Heinemann, UK and Germany, Current developments in international trade - an opportunity for a progressive approach in economics policies

Heinemann provides a novel attack on the woolly style of activists and anti capitalists - who make no attempt - (a) to think about realistic and achievable alternatives, and (b) to check what is it they are really critiquing. He argues that this lack of rigour has led to the status quo stagnating without evolving due to lose critical assessments and the lack of reality factored into both mainstream economics and also the anti globalisation movement. The paper explains the main contemporary developments which are affecting the structures and characteristics of international trade. He suggests that these developments are beyond the scope of traditional trade theories and argues for a completely new optimal trade regime.

\section{Dr. Andrew Mearman, University of West of England, Post-Keynesian economics and the environment}

Mearman explores why Post Keynesian economics has not always managed to include the environment in its scope. He argues that this is because any deviation from orthodoxy, let alone Green Economics, has always met with such opposition from the main stream that any non-orthodox position has had to spent its time fighting to be heard, rather than examining further social and environmental positions. The paper examines the past and potential future contributions made to the economics of the environment by the school of thought known as Post Keynesianism. He suggests that this school uses an approach which emphasises systems, uncertainty, realism and pluralism which could make a useful contribution to environmental debates.

\subsubsection{Interdisciplinary learning}

\section{Professor Jack Reardon, USA, How green are economics textbooks?}

Reardon investigates how main stream economics educates students pertaining to energy, the environment and green economics. He claims that students are imbued with a false sense of optimism for the free market along with a profound sense of ignorance of the interdependence between the economy and the environment. "US economics education is on a collision course with environmental realities," from a green perspective he argues there is little to salvage from mainstream economics and the paper urges a radical reform of economics education.

\section{Dix Sandbeck, Canada, The Edgeworth Box: Beyond Laissez Faire}

Sandbeck builds on the idea in Kennet and Heinemann (2006a) that Green Economics is not afraid of science or the latest scientific discoveries and especially takes much of its data from natural science discoveries, Sandbeck explores the concept further. He shows how new discoveries in physics need to be incorporated into other sciences, and that Newtonian physics could not describe them adequately. The quantum revolution was ignored by economics and he discusses how scientific findings could be reintegrated into economics. 


\subsection{Section D - modernisation and implementation}

\section{Dr. David Toke, University of Birmingham, GM food and the US/EU divide}

In this paper, Toke explores Beck's (2005) ideas on reflexive modernisation and contrasts them with more self-critical precautionary and solutions orientated normative aspects of the idea of the risk society. The aim is to analyse the differences between the USA and EU on environmental issues in general and GM food and crops in particular, using Beck's (2005) 'Risk society' thesis in the process.

\section{Dr. Pritam Singh, UK and Katherine Weisspfennig, Germany, Comparative policy instruments}

Singh and Weisspfennig discuss, in essay form, some of the advantages and disadvantages of pollution instruments. The paper presents and analyses the main pollution control instruments available to governments in a modern economy. It discusses a methodology of how to assess them against a given set of policy objectives. They compare and contrast, methods and instruments based on the Polluter Pays Principle, as well as Pareto efficient mechanisms.

Dr. John Barry, Belfast University, Towards a model of green political economy based on ecological modernisation and economic security

Barry, an expert in social theory, provides an interesting analysis of features of the ecological modernisation debate. From ecological modernisation to economic security, reveals how the triple bottom line is weakest in its economic dimension. He agrees with us that there is a split between those who argue for business as usual and those who want a utopian approach but are not recognising today's reality. He proposes a more radical version of sustainable development and a more practical utopian vision. Barry explores this more radical and appropriate sustainable development conceptualisation, based on the possible links between ecological modernisation and economic security, and examines how this concept could strengthen sustainable development.

\subsection{Section E- some specific examples}

Soma Dey, Bangladesh; The commercialisation of the indigenous economy, and its impact on the environment of Modhupur Garh, Bangladesh

Dey's contribution touches on all the issues we try to cover, including monoculture, feminist issues, other voices and power relations in trade and development. It also deals with the nature of development and the nature of economics as well as environmental considerations and health implications. She shows how the level of destruction of natural sal, (shorea robusta) forest of Modhupur Garh in Bangladesh has pushed the forest dwelling indigenous Garo community into cash crop production, forcing them to move away from a traditional subsistence economy and also affecting the standing of women in the community. The tracking of this process makes this a particularly useful article. 
Liza Griffin, All aboard; power participation and governance in the North Sea Regional Advisory Board

Griffin's paper provides a very useful perspective on what stakeholder theory actually means in practice and its limitations. It also shows how even good initiatives do not always conserve fish stocks and finds power elites in the most unlikely places. It also sheds some light on otherwise concealed power relations in the European Union's new political economic governance procedures, through an empirical investigation of the fisheries stakeholder forum, the North Sea Regional advisory council. She shows that although designed to be more inclusive, stakeholder forums still involve exclusion and uneven power relations that are not always immediately apparent.

\section{Dr. Jeffrey Turk, Interpretive economics in Slovenia}

Turk discusses Slovenia, a transition economy which took a more gradual approach to economic transformation. He offers a biographic narrative approach interviewing some of the key managers who had to implement the specific Yugoslav communist ideology and what they did to make it work in practice. Slovenia is an important country to study since it enjoyed one of the least traumatic transitions of any of the post communist countries.

\section{Dr. Philip Lawn and Dr. Mathew Clarke, Comparing Australia's genuine progress to its} economic growth performance

Lawn and Clarke explore Australia, as an example of a country with a high economic growth level, which enjoyed increased GDP overall of $42 \%$ which was $2.3 \%$ per annum per capita between 1986 and 2003. This is contrasted with its over all well being. GDP, which they argue overestimates well being. It fails to consider a number of important economic costs and non-welfaristic impacts of well-being associated with such a growing economy. The authors estimate a genuine progress indicator for the period 1986 to 2003 and consider the resultant policy implications of this.

\subsection{Section $F$ - discussion and critique}

Professor Jack Reardon Comments on 'Green economics, setting the scene' (Kennet and Heinemann, 2006a)

Professor Reardon critiques the paper by Kennet and Heinemann (2006a) and poses questions of clarification, and suggestions for future research. These include whether to amend or surplant neo classical economics; the role of the corporation; the specific meaning of the precautionary principle and sustainability; and the role of education in promoting green economics.

\section{Call for papers and highlights of forthcoming issues}

The field of green economics is vast, and complex and therefore we believe a themed approach will deliver the most benefit. Papers are therefore invited of a general nature on any subject in green economics, and also on the following themed issues: 
- Political economy with Guest Editor Peter Doran from the University of Belfast

- A special issue on China with papers from the Oxford University Green Economics Conference in April 2007 guest edited by Dr. Yang Chen.

- There will also be an issue focusing on The Complex Mesh of Social and Environmental Justice and how to meet these requirements in Green Economics.

- There is a forthcoming issue on intergenerational equity with Guest Editors Chit Chong and Professor Priscilla Alderson.

- There will also be an issue featuring business and Green Economics, including fascinating articles on stakeholder theory, and will include such issues as organics in Mexico, wood pulp in Norway and the durability of goods.

- Another issue will focus on social policy with various perspectives on pensions.

If you would like to contribute a paper, an abstract should be e-mailed to the Editor, Miriam Kennet, greeneconomicsinstitute@yahoo.com. We also are committed to having at least half the papers being of a more general nature, so do submit your idea, as soon as possible. All articles are at least double blind peer reviewed.

We hope you find the volume as exciting and varied as we did in putting it together and we believe that together they form an important contribution to the emerging field of Green Economics.

\section{Acknowledgement}

The Editor would like to thank Professor Priscilla Alderson, Professor David Simon, Yann Rainneau, Rose Bridger, Volker Heinemann, Victor Anderson and Professor Jack Reardon who advised and helped with the editing of this article.

\section{References}

Anderson, T. and Leal, D.R. (2005) 'Rethinking the way we think', in Dryzek and Schlosberg (Eds.) Debating the Earth, OUP.

Anderson, V. (2006) 'Turning economics inside out', International Journal of Green Economics, Inderscience Publishers, Vol. 1, Nos. 1-2, pp.11-23.

Barry, J. (2005) 'Ecological modernisation', in Dryzek and Schlosberg (Eds.) Debating the Earth, OUP, p.304.

Barry, J. (2007) Environment and Social Theory, Routledge.

Bateman, I. (1997) Environmental and Economics Appraisal, in O. Riordon (Ed.), Environmental Management for Environmental Science, Addison Wesley.

Beck, U. (2005) Politics of Risk Society, in Dryzek and Schlosberg (Eds.), OUP.

Bookchin, M. (2005) Society and Ecology, in Dryzek and Schlosberg (Eds.), OUP.

Bramwell, A. (1989) Ecology in the 20th Century, New Haven: Yale University.

Bridger, R. (2006) 'Redefining efficiency in food supply chains', Conference Proceedings. The 2006 Green Economics Conference and Intergenerational Equity, Holism and Long-Termism Conference, Mansfield College, Oxford University, Green Economics Institute Publication, 8 April. 
Chong, C. (2006) 'Restoring the rights of future generations', International Journal of Green Economics, Vol. 1, Nos. 1-2, pp.103-121.

Common, M. and Stagl, S. (2006) Ecological Economics: An Introduction, Cambridge.

D’Agostino, F. (2006) 'Two conceptions of reason', Economy and Society, Vol. 35, 1 February, pp.1-21.

Daly, H.E. (1974) 'The economics of the steady state', American Economic Review (Papers and Proceedings), May, Vol. 64, No. 2, pp.15-21.

De Beauvoir, S. (1949) The Second Sex (Le Deuxième Sexe) [in French], ISBN 0679724516.

De Waal, F. (2005) Our Inner Ape, Granta Books.

Diamond, J. (2005) Collapse: How Societies Choose to Fail or Survive, Allen Lane.

Dicken, P. (1986) Global Shift Industrial Change in a Turbulent World, London: Harper and Row.

Dobson, A. (2000) Green Political Thought, Abingdon Routledge.

Dryzek, J.S. (1997) The Politics of the Earth Environmental Discourses, Oxford.

Dryzek, J. and Schlosberg, D. (2005) Debating the Earth, Oxford University Press.

Firth, M. (2006) 'UN report women denied representation: making the war on poverty hard to win', Independent, 8 March, p.2.

Freeman, R.E. (1984) Strategic Management: A Stakeholder Approach, Boston, MA: Pitman.

Ghilligan, C. (1982) In a Different Voice, Cambridge, MA: Harvard University Press.

Goudie, A. (1997) The Human Impact Reader, Blackwell Publishers.

Grimwade, N. (1989) International Trade, New Patterns of Trade, Production and Investment, Routledge.

Hawken, P., Lovins, A. and Lovins, L.H. (2005) The Next Industrial Revolution, in Dryzek and Schlosberg (Eds.).

Hecht, J. (2007) Big, Bad and Furry, New Scientist, 3 February, p.33.

Ietto-Gilies, G. (2006) Transnational Corporations, International Production, Concepts, Theories and Effects, Edward Elgar.

Jacobs, M. (1991) The Green Economy, Pluto Press.

Kennet, M. (2006) 'How do current purchasing and supply chain methods in large international companies affect stakeholders? Contrasting stakeholder and holistic, green economics approaches', 2006 Green Economics and Intergenerational Equity, Holism and Long - Termism Conference, Conference Oxford University Proceedings, 8 April.

Kennet, M. and Heinemann, V. (2006a) 'Green Economics setting the scene', International Journal of Green Economics, April, Vol. 1, Nos. 1-2, pp.68-103.

Kennet, M. and Heinemann, V. (2006b) 'Long termism, holism, and intergenerational equity in economics', 2006 Green Economics and Intergenerational Equity, Holism and Long - Termism Conference. Conference Oxford University Proceedings, 8 April.

Korhonen, J. and Strachan, P. (2004) 'Editorial: towards progress in industrial ecology', Progress in Industrial Ecology, Inderscience Publishers, pp.1-24.

King, Y. (2005) 'An ecological feminism and a feminist ecology', in Dryzek and Schlosberg (Eds.) Environmental Discourses.

Lawson, T. (1997) Economics and Reality, Routledge.

Lawson, T. (2007) 'An orientation for green economics?', International Journal of Green Economics.

Lean, G. (2005) 'Global warming approaching point of no return, warns leading climate expert', Independent, 23 January.

Lynas, M. (2007) 'The hellish vision of life on a hotter planet', Independent, 3 February, p.3.

Maathai, W. (2007) 'Unbowed', One Woman's Story, London: William Heinemann. 
Marchant, C. (1980) Environment, Capitalism and Socialism, Resistance Books 1999.

McCarthy, M. (2007) 'UN delivers definitive warning on dangers of climate change', Independent, 3 February, p.2.

Meilkle, S. (1994) Aristotle's Economic Thought, Clarendon Paperbacks.

Mies, M. (1986) Patriarchy and Accumulation on a World Scale, Women in the International Division of Labour, Zed Books, p.56.

Mill, J.S. (1859) On Liberty, Penguin Classics 1974.

Mithen, S. (2003) After the Ice, a Global Human History 20,000 to 5000 BC, London: Phoenix.

Newman, S. (2007) '5 minute interview: Wangari Maathai, Environmentalist and former Kenyan Environment Minister', Independent Newspaper, 15 February.

Ocampio, J.A. (2006) UN Development Goals Report, UN.

Pachauri, R. (2007) 'The fourth assessment of the intergovernmental panel on climate change', IPCC Report.

Pearce, F. (2007) 'But here's what they didn't tell us', New Scientist, 10 February.

Pigou, A.C. (1920) The Economics of Welfare, London: McMillan.

Ponting, C. (1991) A Green History of the World the Environment and the Collapse of Great Civilisations, Penguin Books.

Porritt, J. (1984) Seeing Green: The Politics of Ecology Explained, London: Blackwell.

Raudsepp-Hearne, C., Reid, W., Watson, R. and Zakri, A.H. (2005) 'UN Millennium Ecosystem Services Assessment', Living Beyond Our Means: Natural Assets and Human Well-being, Island Publications.

Reardon, J. (2007) 'Green economics setting the scene, a critique', International Journal of Green Economics, Vol. 1, Nos. 3-4.

Redclift, M. (1987) Sustainable Development: Exploring the Contradictions, London: Meuthen.

Rostow, W.W. (1990) Theorists of Economic Growth from David Hume to the Present, Oxford University Press.

Sachs, J. (2005) The End of Poverty, How can we Make it Happen in our Lifetime, London: Penguin.

Salleh, A. (1997) Ecofeminism as Politics, Zed Books.

Sallins, M. (1974) Stone Age Economics, Tavistock Publications.

Schmeidheiny, S. (1992) 'Changing course: a global business perspective on development and the environment', Business Council for Sustainable Development, Cambridge: MIT Press.

Schumacher, E.F. (1973) Small is Beautiful, Bloom Holistic Revolution Penguin Press 2000.

Simmon, D. (2007) 'Urbanisation and global environmental change: new intergenerational challenges', International Journal of Green Economics, Inderscience, Vol. 1, Nos. 3-4, pp.299-306.

Smith, J. (2006) 'Watchout patriarchy is making a comeback', Independent, 8 February, p.29.

Springett, D. (2006) 'Managing the narrative of sustainable development: "discipline" of an inefficient concept', International Journal of Green Economics, Inderscience, Vol. 1, Nos. 1-2, pp.50-68.

Stern, N. (2006) Stern Review on the Economics of Climate Change, HM Treasury Cambridge University, 30 October.

UNICEF Report (2007) Childhood Well-being in Industrialised Countries, 14 February.

Viles, H. and Spencer, T. (1995) Coastal Problems, Geomorphology, Ecology and Society at the Coast, Edward Arnold.

Welford, R. (2007) 'Corporate social responsibility and Buddhist economics', International Journal of Green Economics, Inderscience, Vol. 1, Nos. 3-4. 


\section{Bibliography}

Bansal, P. and Howard, E. (1997) Business and the Natural Environment, Butterworth-Heinemann. Brundtland, G.H. (1987) Our Common Future, World Commission on Environment and Development.

Carruthers, D. (2005) Opposition to Orthodoxy: The Remaking of Sustainable Development, in Dryzek and Schlosberg (Eds.), OUP.

Carson, R. (1962) The Silent Spring, Houghton Mifflin.

Confucius, M. (540 BCE) Analects of Confucius (論語).

Dorran, P. (2006) 'Streetwise provocations; The global justice movements take on sustainable development', International Journal of Green Economics, Vol. 1, Nos. 1-2, pp.151-169.

Foucault, M. (1969) The Archaeology of the Mind, London: Routledge.

Hardin, G. (1968) The Tragedy of the Commons Science, Vol. 162, pp.1243-1248.

Lovelock, J. (1979) The Gaia Hypothesis - A New Look at Life on Earth, OUP, pp.1-12.

Meadows, D. (1972) The Limits to Growth a Report for the Club of Rome's Project on the Predicament of Mankind, 2nd ed., New York Universe Books.

Mies, M. (1999) 'Patriarchy and accumulation on a world scale', in M. Scott Cato and M. Kennet (Eds.) Green Economics; Beyond Supply and Demand to Meeting People's Needs, Green Audit, Aberystwth.

Mithen, S. (1996) The Prehistory of the Mind, The Search for the Origins of Art, Religion and Science, Phoenix.

Nathan, S. (2007) 'Fusion future', The Engineer Nuclear Fusion, 12-25 February.

Perkins, E. and Kuiper, E. (2005) 'Introduction: exploring feminist ecological economics', Feminist Economics, November, Vol. 11, No. 3, pp.107-150.

Riordan, O. (Ed.) (1995) Environmental Science for Environmental Management, Longman.

Roberts, N. (1998) The Holocene: An Environmental History, Blackwells.

Roegens, G. (1976) The Entropy Law and the Economic Problem, in H.E. Daly and K. Townsend (Eds.) Valuing the Earth Economics, Ethics Ecology, Cambridge, MA: MIT Press.

Starik, M. (1995) 'Should trees have managerial standing: towards an extension of stakeholder status for non human nature', Journal of Business Ethics, Vol. 14, pp.207-217.

Wall, D. (1999) Earth First and the Anti Roads Movement: Radical Environmentalism and Comparative Social Movements, London: Routledge.

Woodin, M. and Lucas, C. (2005) Green Alternatives to Globalisation, Pluto Press. 